\title{
Local Community Participation in Restoration of Watersheds in Uganda
}

\author{
S. Akello ${ }^{1, *}$, N. Turyahabwe ${ }^{1}$, H. Sseguya ${ }^{3}$, P. Okullo ${ }^{2}$, J.G. Agea ${ }^{1}$ \\ ${ }^{1}$ Department of Extension and Innovation Studies, College of Agricultural and Environmental Sciences, Makerere, \\ University, P. O. Box 7062, Kampala- Uganda \\ ${ }^{2}$ Nabuin Zonal Agricultural Research and Development Institute, P.O Box 132, Moroto, Uganda \\ ${ }^{3}$ International Institute of Tropical Agriculture, Regional Hub for Eastern Africa, P.O. Box 34441, Dar es Salaam, Tanzania \\ *Corresponding author: sarahakellok@yahoo.com
}

\begin{abstract}
Despite the involvement of the local community in Awoja watershed activities, restoration was not fully achieved. Studies on community participation in Awoja watershed have focused on its importance with little known on the extent to which they participate, yet the level of community participation determines the success of restoration of watersheds. This study analysed the extent of local community participation in restoration of Awoja watershed of Eastern Uganda. It was conducted in Ngora district and respondents were asked about two restoration sites of FIEFOC and COBWEB. Data were collected from 237 respondents using a questionnaire from April to July 2015. Descriptive analysis and independent t-test were employed to analyze data. Results indicated that overall level of local community participation in Awoja was average with varied patterns in social, economic and environmental participation. Results showed significant differences between level of participation in overall $(\mathrm{P}=0.034)$ and environmental $(\mathrm{P}=0.044)$ in FIEFOC and COBWEB restoration sites. Community involvement at all project phases should be encouraged to create a sense of ownership and guidance in similar upcoming projects.
\end{abstract}

Keywords: local community, representation, watershed restoration and Eastern Uganda

Cite This Article: S. Akello, N. Turyahabwe, H. Sseguya, P. Okullo, and J.G. Agea, "Local Community Participation in Restoration of Watersheds in Uganda.” American Journal of Environmental Protection, vol. 5, no. 2 (2017): 25-32. doi: 10.12691/env-5-2-1.

\section{Introduction}

Globally, local community participation in watershed restoration is a widely accepted phenomenon. This emanates from the relationships between nature, people and culture [13,25,32]. According to Devi [8], the low level of community participation in Odisha watershed of India was due to economic and socio-cultural factors. These created opportunities for the rich and educated; leaving out landless and vulnerable households. In Ethiopia for instance, failure in watershed restoration programes was due to inadequate participation of the community [22,30]. In East Africa, unsuccessful programes in watershed restoration were attributed to lack of transparency and accountability in the restoration process [10,19]. Whereas the involvement of the watershed adjacent community in restoration is commended, success depends on the extent of their participation [8].

According to Devi [8] and Sseguya et al., [29], participation of shareholders is varied along the continuum by degree, ranging from tokenism to real empowerment. Bass, Dalal-Clayton and Pretty (1995) suggest four levels of participation, ranging from contractual, to consultative, to collaborative and to collegiate. Participation is important in restoration projects in rural areas [23]. The principle aim of community participation is to involve people in all stages from decision making to benefit sharing. According to Binod [5], willingness to participate among community is varied and is hinged on the nature of the activities like decision making, having different groups participating at different levels. The level of participation where relinquishing control of ownership of program processes (planning, implementation, monitoring and evaluation etc.) to the community is the greatest level of participation. Several scholars assert the importance of community participation in watershed programs right from the 1990s but success has remained elusive. As noted by Masika [14], participation must not be seen as an end in itself but a means to achieving collective action. Supporting notional discourse on participation predictors by Devis [8], Bagherian [4] and Perkins, et al. [21] note that the level of community participation is dependent on social, economic and environmental factors. Therefore, the magnitude of community participation in restoration efforts is pivotal in restoration success.

For the last two decades, restoration of watersheds in Uganda has been effected by both the government and development partners through projects [17,34]. In the Eastern part of the country, two such projects were implemented between 2007 and 2013 while involving the community. The projects implemented were the Farm Income Enhancement and Forest Conservation (FIEFOC) 
and the Community Based Wetland and Biodiversity (COBWEB). FIEFOC project provided assistance to private forest owners to plan for and manage their forests, especially those located in watersheds. This was through training, enrichment planting, woodlot establishment and; establishment of soil and water conservation technologies (MWE, 2009). The COBWEB project aimed at restoring biodiversity of endangered and vulnerable bird and fish species (crested cranes, shoebills and fox weavers) by creating community conservation areas in Lake Bisina of Awoja watershed area. This was through training on tree nurseries establishment, planting trees, establishment of alternative sources of income for the community through putting up an ecotourism site, initiation of a Savings and Credit Cooperative Organisation (SACCO) as an approach to restore the watershed. The activities of the two projects were carried out in groups to encourage high local participation levels in watershed restoration [9,34].

Inspite the participation of the local community in groups, restoration of Awoja watershed through the project was not full realized in 2014 based on [17,34]. Up to this date this watershed further faces continuous degradation [2]. Studies on community participation in Awoja watershed have focused on the importance of community participation with little known on the extent to which they participate, yet the level of community participation determines the success of restoration of watersheds [13,34]. This paper will inform practice on how to better engage with the local community in restoration activities and how the level of their participation is significant to successful watershed restoration in Ngora district and Uganda. Unless the extent of community participation in restoration efforts is well understood, degradation of Awoja watershed will persist impacting on several households that derive their livelihoods from it.

\section{Methodology}

\subsection{Research Method}

This study employed an ex post facto crossectional research design using mixed methods from both primary and secondary data sources. According to Yin (2006), this research design is used after an event has occurred and the researcher does not control the variables during the even like watershed restoration project. From the perspective of social science research, the ex post facto research design aims at establishing the possible relationship among the variables by observing the present condition and looking back for some possible contributory factors [12]. This design was found to be appropriate for this study because this investigation was carried after the intervention. Crosssectional because data was collected at one point in time. The primary source was based on data collected through semi-structured interviews conducted in the Awoja watershed. Key informant Interviews were conducted with the watershed management group members, Ngora District Local government staff (NDLG), staff from IUCN, Nature Uganda, wetlands management department, Non-Governmental Organizations. The Key informant interviews were conducted and recorded on a voice recorder in verbatim. The Materials used in the study included Project reports, Ngora District Development Plans, published journal articles, unpublished dissertations and secondary data sources. Qualitative methodology was used for this study and Grounded theory was selected because interviews constitute the main source of data.

Methods and techniques used in data collection. Qualitative data was collected through semi-structured interviews and designed checklists. Key informant Interviews, focus group discussion and observations were among the techniques used in this study. Since in qualitative research the focus is rather on data obtained from the situation than the number of samples, therefore researcher continued sampling until saturation was reached where no new information is gotten. Quantitative data was collected through survey using a questionnaire. A team of four researchers used a household-level questionnaire to collect the data between April and July 2015 a period when the vegetation has regenerated. The research team was first trained before starting data collection to get acquitted with the study. Preliminary activities were held so as to clarifying the study aims. The activities included joint clarification of confusing and ambiguous questions and their meanings in context of the study. Questionnaires were pre-tested for five days in Gweri sub-county in Soroti district with 33 respondents. This number is adequate for a pre-test when one intends to carry out a survey [35].

A household survey was then carried out in the two restoration sites of FIEFOC (Mukura) and COBWEB (Kapir). The samples were drawn from the local community that live in the watershed as they obtain numerous benefits from them but also greatly influence the ecosystem processes together with stakeholders like the District local government, Non-governmental Organisations, private sector and donors. The sample size was determined using Krejcie and Morgan (1970) table and formula, helpful in determining sample sizes when the numbers of participating population is known. Four villages of Ariet and Puna in Moru Kakise parish; Omitto and Kakor in Omitto parish were randomly selected out of the eight implementing villages, two from each sub county. The households interviewed were selected using simple random sampling technique for respondents to have equal chances of being chosen from the list provided by the chair persons of the groups. Each group on average were 40 in number in Mukura for FIEFOC and 50 households in Kapir for COBWEB Projects.

In total 112 respondents in Mukura and 125 in Kapir from the four villages chosen were interviewed. The targeted number of 237 respondents were to be interviewed only 235 individuals were fully interviewed. The respondents were either the head of the household or any member of the household who was knowledgeable on the group activities. The unit of analysis was the household. Structured and semi structured questions aided the survey process. The respondent's level of participation during the restoration of Awoja watershed was measured using three sub-scores and a composite score. These were on economic participation, social participation and environmental participation in Awoja watershed. In measuring participation, an instrument consisting of 15 items was developed and used. Five items were used to 
obtain information on each of the 3 sub scores categories on level of participation in Awoja watershed. The unit of analysis was the household head.

Information was also collected on socio-demographic, economic and spatial characteristics. These included age, education level, marital status, grazing sites at the watershed, cultivation sites, land sizes and ownership. Data was also collected on the group formation process, stages and level of participation These included group initiation, activities, who participated, how they participated, when the participated, where they participated, what they participated in and their level of involvement.

This study was conducted in a portion of Awoja watershed of Eastern Uganda. This was based on its high watershed degradation rate in the last two decades estimated at $20 \%$, compared to the national average of $11 \%$ [17]. The watershed also had the highest perceived degradation rate of $76 \%$ compared to $63 \%$ from Lake Victoria crescent and 41\% in the South Western farmlands of Uganda (Turyahabwe et al., 2013). Out of the fourteen districts traversed by the watershed, Ngora was chosen because it occupied a greater part of Awoja. It also piloted the two restoration intervention projects by the FIEFOC and COBWEB. Ngora district is found in North Eastern Uganda which lies approximately between latitudes $1^{0} 10^{\prime}$ and $1^{0} 35^{\prime}$ North and longitudes $33^{0} 30^{\prime}$ and $34^{0} 20^{\prime}$ East.

Mukura and Kapir sub counties were chosen because they were project implementing sub counties, besides having the highest average household sizes of 5.3 for Mukura and 5.2 for Kapir. These household sizes were above the country's average of 4.7 [31]. Moru-Kakise parish for FIEFOC and Omitto for COBWEB were chosen purposively because they were executing parishes. Kakor and Omitto villages in Omitto parish; and Ariet and Puna in Moru- Kakise parish were randomly selected out of the 8 implementing villages.

\subsection{Data Analysis}

Content analysis was used to analyse data gathered through focus group discussion and key informant interviews. The data collected from the survey was entered into SPSS version 21 in order to perform descriptive analysis and inferential analysis. Descriptive analysis was carried out to generate the frequencies, means and standard deviation from the drawn samples. This enabled us to understand the nature of the respondents that influenced participation during Awoja watershed restoration project interventions. An independent t-test was used to compare mean values of the two samples drawn from FIEFOC and COBWEB participating population. For measuring level of participation, questions on dependent variable were asked and rated against indicators of social, economic and social participation. These indicators were scaled as an integer value in a range of one to three, where one meant low, two for average and three high on one particular aspect of participation. A set of socio demographic questions as categorical variables were assigned independent variables to test the variation with level of participation. These were measured depending on their appropriateness.

\section{Results and Discussions}

The researcher obtained information regarding the level, stages of community participation and respondents who participated at the various stages from the design to evaluation stage. For one to become a registered member, the constitution demanded that each paid for membership a fee of between US\$ 0.14 to 0.6 depending on the group in order to join a community watershed group. The stages of participation during the interventions (Table 1). From the findings, the project cycles did not provide for the involvement of the community at the design and planning stages which are very critical for the success of restoration. If the community were involved at these two stages of designing and planning of the two projects, some of the preferred information on livestock keeping, climate change and fruit growing would have been given a priority during dissemination much as the information disseminated by the projects were equally important.

Table 1. Stages of FIEFOC and COBWEB project interventions on restoration of Awoja depicting the level of community involvement

\begin{tabular}{|c|c|c|c|c|}
\hline $\begin{array}{l}\text { PARTICIPATION } \\
\text { PROJECT CYCLE }\end{array}$ & $\begin{array}{c}\text { PLANNED } \\
\text { (FIEFOC-MUKURA } \\
\text { SITE) }\end{array}$ & $\begin{array}{c}\text { EXECUTION } \\
\text { (FIEFOC-MUKURA } \\
\text { SITE) }\end{array}$ & $\begin{array}{c}\text { PLANNED } \\
\text { (COBWEB- KAPIR SITE) }\end{array}$ & $\begin{array}{c}\text { EXECUTION } \\
\text { (COBWEB- KAPIR } \\
\text { SITE) }\end{array}$ \\
\hline DESIGN & $\begin{array}{c}\text { FOREST SECTOR } \\
\text { SUPPORT DEPARTMENT } \\
\text { (FSSD), FAO, DONORS }\end{array}$ & FSSD, FAO, DONORS & GEF, UNDP \& IUCN & GEF, UNDP \& IUCN \\
\hline PLANNING & $\begin{array}{l}\text { FSSD, FAO, DONORS, } \\
\text { DLG, COMMUNITY }\end{array}$ & FSSD, FAO , DONORS & $\begin{array}{l}\text { IUCN,NU,UNDP,WMD, } \\
\text { UWS,UWA, DLG, } \\
\text { COMMUNITY }\end{array}$ & $\begin{array}{c}\text { IUCN,NU,UNDP,WMD, } \\
\text { UWS\& UWA }\end{array}$ \\
\hline IMPLEMENTATION & $\begin{array}{l}\text { FSSD, DLG \& } \\
\text { COMMUNITY }\end{array}$ & $\begin{array}{l}\text { FSSD, LG \& } \\
\text { COMMUNITY }\end{array}$ & $\begin{array}{l}\text { NU,UWS,WMD,IUCN,UWA } \\
\text { LG \& COMMUNITY }\end{array}$ & $\begin{array}{c}\text { NU,LG \& } \\
\text { COMMUNITY }\end{array}$ \\
\hline MONITORING & FSSD \& DLG & $F S S D \& D L G$ & NU,UWS,WMD,IUCN,UWA & $\begin{array}{c}\text { IUCN, NU\& NGORA D } \\
L G\end{array}$ \\
\hline EVALUATION & $\begin{array}{l}\text { FSSD, CONSULTANT, } \\
\text { DLG }\end{array}$ & CONSULTANT \& FSSD & $\begin{array}{l}\text { NU, UWS, WMD, IUCN, } \\
\text { UWA, NDLG, COMMUNITY, } \\
\text { CONSULTANT }\end{array}$ & $\begin{array}{l}I U C N, N U \\
\text { CONSULTANT }\end{array}$ \\
\hline
\end{tabular}

FSSD* Forest Sector Support Department 


\subsection{Stages of Participation}

The community is the main beneficiaries of the restoration interventions. Besides interacting with watersheds on daily basis, they are conversant on issues related to watershed and responsible for the degradation on the watershed. Their exclusion at the design and planning stages of the project cycle was an over sight. The community livelihoods depend on the watersheds. Their absence at the design and planning stages led to the omission of their ideas on how best restoration of Awoja could have been achieved. In addition their constant contact with the watershed makes them understand the status better. Therefore leaving them out at the design and planning stages of the project cycle was an over sight. This explains why it was relatively hard to embrace the intervention having been involved partially in the entire project. The involvement of the community at the different stages of the intervention could have motivated the community to better discuss issues that concern them at the design and planning stages.

At the implementation stage, the community was highly involved in several activities. The monitoring and evaluation stages of the interventions equally left out the community. Whereas the planned phases of the two restoration projects were inclusive, the actual execution stages were exclusive of specifically the community, key stakeholders in restoration process. The community were excluded in the last two stages of the intervention, the monitoring and evaluation stages. Their involvement should have acted as a point of self-evaluation of the projects as well as lessons to carry forward in case a similar project is introduced in the watershed.

From descriptive analysis, frequencies were generated to ascertain the socio demographic characteristics of the respondents and their influence on participation in the restoration of Awoja watershed. These were gender, marital status, education, primary occupation, other sources of income and membership in the group. The socio demographic characteristics of the respondents in the study area (Table 1.) were:

- Gender: The data showed that $58.6 \%$ of the respondents were female and $41.4 \%$ male.

- Marital status: The records of the survey indicated that majority (69.6\%) of the respondents were married, $12.7 \%$ single, $12.7 \%$ widowed and $5.1 \%$ separated.

- Education: The formal education levels were analysed as follows; primary level that take 7 years had the majority (66.7\%), secondary level ordinary and advanced level (4 and 6 years) had 16.7\%, Tertiary ( 2 and 5 years) diploma and above had $3.4 \%$ of the respondents. The data revealed that the level of education in study area was relatively average. This can be explained from the Universal primary program by the government.

Primary occupation: Farming was the main occupational activity carried out by (81.4\%) of the respondents. Business was the second primary occupation carried out by $14.8 \%$ of the respondents and formal employment was ranked third with $3.8 \%$. Results of the analysis also indicated that $54 \%$ of the respondents did not have any other source of income.
Table 2. Socio demographic characteristics of the respondents

\begin{tabular}{|c|c|c|}
\hline Variables & Frequency & Percentage \\
\hline \multicolumn{3}{|l|}{ Gender } \\
\hline Female & 89 & 41.4 \\
\hline Male & 139 & 58.6 \\
\hline \multicolumn{3}{|l|}{ Marital Status } \\
\hline Married & 165 & 69.6 \\
\hline Single & 30 & 12.7 \\
\hline Separated & 12 & 5.1 \\
\hline Widowed/Widower & 30 & 12.7 \\
\hline \multicolumn{3}{|l|}{ Education level } \\
\hline Non & 29 & 12.2 \\
\hline Primary & 158 & 66.7 \\
\hline Secondary & 42 & 17.7 \\
\hline Tertiary & 8 & 3.4 \\
\hline \multicolumn{3}{|l|}{ Main occupation } \\
\hline Farmer & 193 & 81.4 \\
\hline Business & 35 & 14.8 \\
\hline Formal employment & 9 & 3.8 \\
\hline \multicolumn{3}{|l|}{ Other sources of income } \\
\hline Non & 128 & 54.0 \\
\hline Sale of agric. Products & 52 & 21.9 \\
\hline Fishing & 39 & 16.5 \\
\hline Brewing & 7 & 3.0 \\
\hline Boda boda & 3 & 1.3 \\
\hline Building & 3 & 1.3 \\
\hline TOT climate change & 2 & 0.8 \\
\hline Politics & 1 & 0.4 \\
\hline Apiary & 1 & 0.4 \\
\hline Bread baking & 1 & 0.4 \\
\hline \multicolumn{3}{|l|}{ Membership in groups } \\
\hline More than one & 216 & 91.1 \\
\hline Watershed group & 21 & 8.9 \\
\hline
\end{tabular}

Whereas $21.9 \%$ had sales of products as their alternative source of income, $16.5 \%$ said sales from fish was their other source, 3\% brewing, 1.3\% Boda boda (bike riding), $1.3 \%$ brewing, $0.8 \%$, training of trainers (TOT) climate change, $0.4 \%$ politics, $0.4 \%$ apiary and 0.4 bread making.

Local group membership: The data showed that, the majority $(91.9 \%)$ of the respondents belonged to other local groups other than watershed and only $8.9 \%$ belonged to community watershed.

\subsection{Level of Participation}

Results on respondent's level of participation in Awoja watersheds were assessed in three sub-scores and overall score. The sub-scores were on social, economic and environmental participation in Awoja watershed restoration site. In measuring the participation levels, an instrument consisting of 20 items was developed and used. Ten items were meant to generate data on the social participation, 5 items on economic participation and 5 items on the environmental participation in Awoja 
watershed. The results indicated that the level of participation in Awoja watershed was average; however, communities were more involvement in social rather than economic and environmental activities. A summary of the overall scores of the respondent's participation is presented (Table 3).

Table 3. Comparison on the level of Participation by type

\begin{tabular}{lcc}
\hline Overall participation & Frequency $(\mathbf{n}=\mathbf{2 3 7})$ & Percentages \\
\hline Low (20-33) & 18 & 7.6 \\
Average (34-47) & 194 & 81.9 \\
High (48-60) & 25 & 10.5 \\
Social participation & & \\
Low (10-14) & 9 & 3.8 \\
Average (15-19) & 59 & 24.9 \\
High(20-25) & 169 & 71.3 \\
Economic participation & & \\
Low (5-8) & 176 & 74.3 \\
Average (9-12) & 61 & 25.7 \\
High(13-15) & 0 & 0 \\
Environmental participation & & \\
Low (5-8) & 57 & 24.1 \\
Average (9-12) & 146 & 61.6 \\
High(13-15) & 34 & 14.3 \\
\hline
\end{tabular}

The visual expression of the details on the levels of participation by different types (Figure 1).

Based on Figure 1, in overall participation, $7.6 \%$ of the respondents obtained low scores, $81.9 \%$ obtained average scores and $10.5 \%$ of the respondents scored highly. The mean score of the overall respondents were 41.667, which was slightly higher than 30 , (the mid-point between lowest possible score (20) and the highest possible score (60). The data indicated that the respondent's participation in Awoja watershed was moderate.

Social participation: Data also indicated that respondent's social participation in Awoja watershed was high. In this regard data showed that, $3.8 \%$ of the respondents obtained low scores; $24.9 \%$ of the respondents scored moderately and $71.3 \%$ of the respondents scored highly. The mean score of the respondents was 21.1, and the standard deviation of the data was 3.12 which were slightly higher than 17.5, (the mid-point between lowest possible score (10) and the highest possible score (30). The data showed that there was high social participation level.

Economic participation: Based on data, $74.3 \%$ of respondents scored low, while $25.7 \%$ of the respondents scored average, none of the respondents scored highly. The mean score of the overall respondents of economic participation were 5.122, which was slightly higher than 5, (the mid-point between lowest possible score (5) and the highest possible score (15). The data indicated that the respondent's economic participation in Awoja watershed was low.

Environmental participation, $24.1 \%$ of the respondents obtained low scores, $61.6 \%$ of the respondents obtained average scores while $14.3 \%$ of the respondents scored high environmental participation. The mean score of the overall respondents were 10.234 which was slightly higher than 10, (the mid-point between lowest possible score (5) and the highest possible score (15). The data indicated that environmental participation in Awoja was average.

\subsection{Comparison of Participation in the Two Restoration Site}

A two sample independent t-test was carried out to compare the values of the means from two samples drawn from the FIEFOC and COBWEB restoration sites. According to Amin (2004), this is meant to compare the actual difference between two means in relation to the variation in the data. The differences in the mean values are shown (Figure 2).

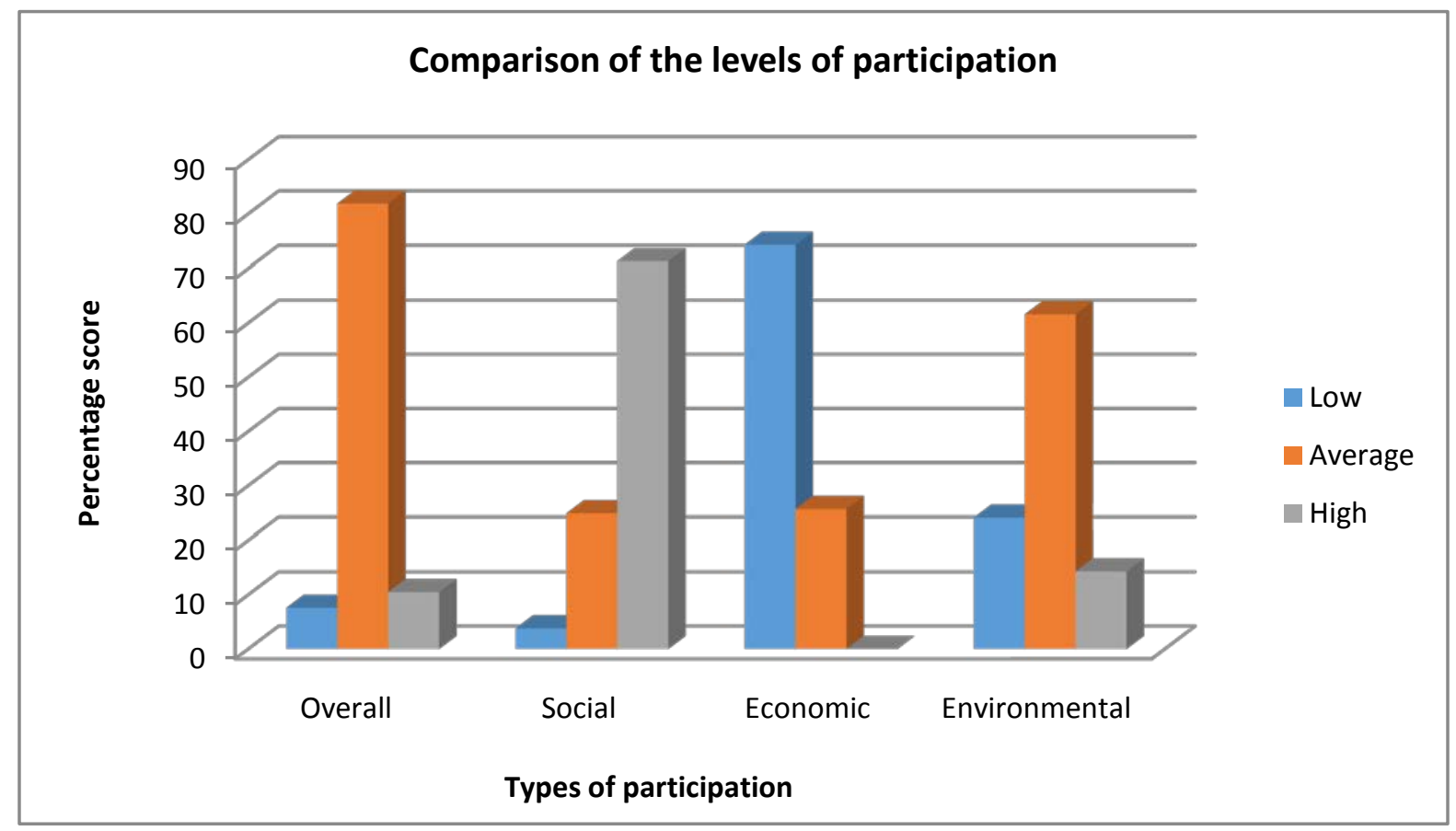

Figure 1. The level of participation assessed against the different types 


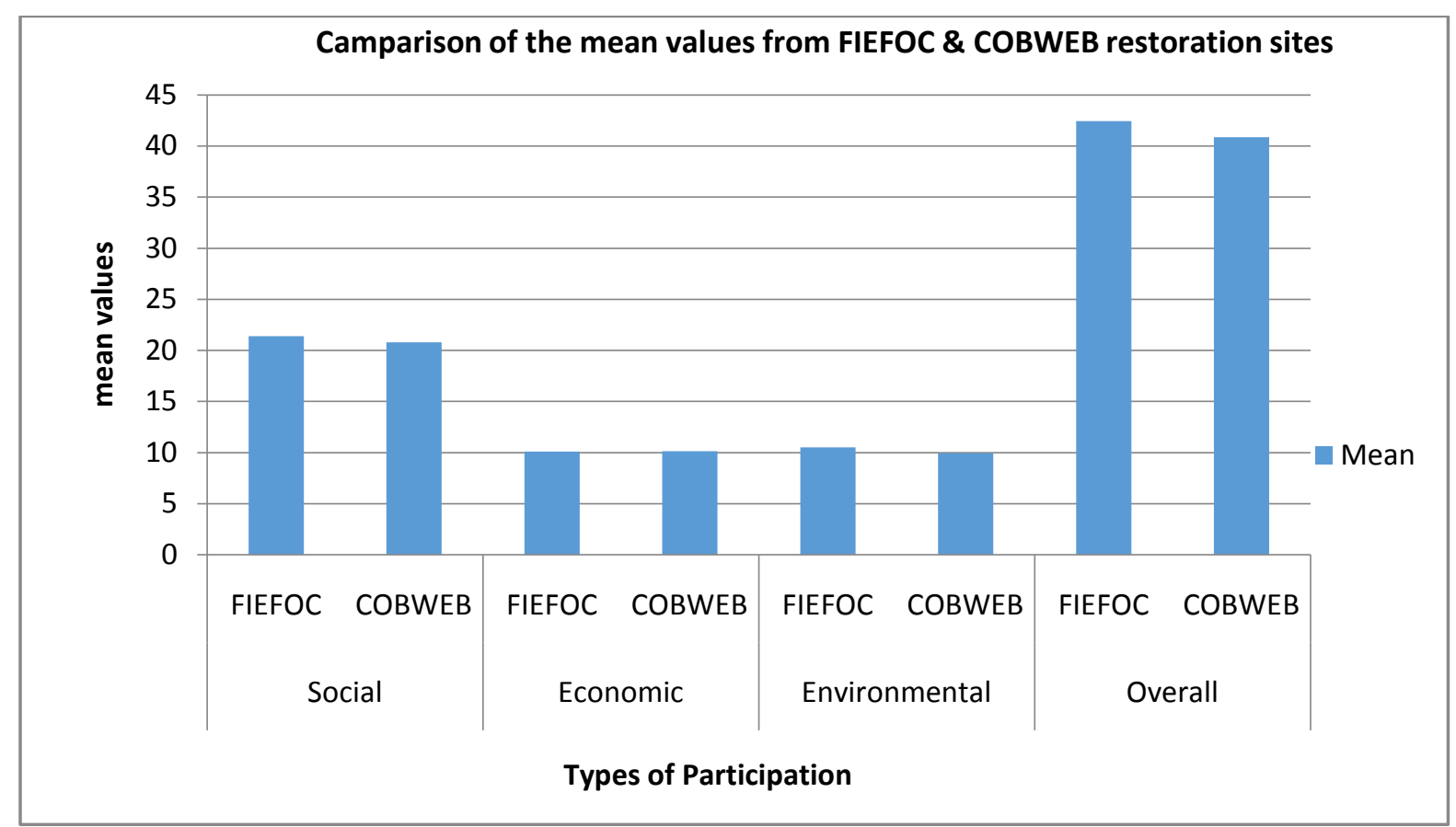

Figure 2. Difference in the mean values from the two different restoration sites

Table 4. Comparison on participation level by type

\begin{tabular}{lccccc}
\hline & HH type & N & Mean & Std. Deviation & Std. Error Mean \\
\hline \multirow{2}{*}{ Social Participation } & FIEFOC & 112 & 21.4018 & 2.91458 & 0.27540 \\
& COBWEB & 125 & 20.8000 & 3.32148 & 0.29708 \\
Economic Participation & FIEFOC & 112 & 10.1071 & 2.07237 & 0.19582 \\
& COBWEB & 125 & 10.1360 & 2.14530 & 0.19188 \\
Environmental Participation & FIEFOC & 86 & 10.5233 & 2.03919 & 0.21989 \\
& COBWEB & 125 & 9.9440 & 2.03717 & 0.18221 \\
Overall participation & FIEFOC & 86 & 42.4535 & 5.19424 & 0.56011 \\
& COBWEB & 125 & 40.8800 & 5.30763 & 0.47473 \\
\hline
\end{tabular}

Although results indicated that environmental participation in both FIEFCO and COBWEB were significant $(\mathrm{P}=0.044)$, the level of education of the individuals in the FIEFOC site from 0' level and above was higher (28\%) than those in COBWEB restoration that was $15 \%$. This explains why there was higher environmental participation in FIEFOC (10.5233) compared to COBWEB (9.944) (Table 4). The findings indicate that $31 \%$ of the FIEFOC individuals interviewed were either formally employed or business persons unlike in COBWEB site where only $7.2 \%$ belonged to this category. This partly explains why overall participation was higher in FIEFOC than COBWEB site showing significance difference in the levels $(\mathrm{P}=0.034)$ in both restoration sites, with FIEFOC (42.4535) showing higher participation compared to COBWEB (40.8800) at the confidence level of $95 \%$. However, there were no significance differences in how the community participated in social and economic activities during the restoration of Awoja watershed in both FIEFOC and COBWEB sites, much as the site had more number of formally employed individuals and those engaged in business ventures. This is in agreement with findings of previous studies as mentioned in literature reviewed from Bagherian [4] and Dolisca (2006).
Whilst the level of participation in development programs are different, with local community participating at varied levels, according to Sseguya [29], four levels of participation, ranging from contractual, to consultative, to collaborative; to collegiate are recognised. This study finding on average level of participation (consultative) in overall participation in Awoja, agrees with those of Bass (2010), [14] in Uganda and Bagdi \& Kurothe (2014) in Vidarbha region of Maharashtra in India on how rarely the development agencies engage in collaborative projects to achieve high levels of participation. Furthermore, content analysis indicated that Awoja watershed community were left out at the design and planning stages of the restoration projects hence a setback in attaining collegiate relationships where local community control the process as noted by Cornwall and Jewkes (1995).

However, this study disputes a finding by Devi [8], on better levels of participation in the NGO restored watershed than Government. The results of the current study indicated that there were no significant differences in the levels of social and economic participation for both FIEFOC (government) and Non-governmental organisations (COBWEB) sites. Meaning whether in NGO or government spear headed projects, community will participate in restoration activities if the benefits to them outweigh the 
costs involved. The level of participation and sustainability depends on the appropriateness of the approach and process used in participation. Whereas there have been policy reforms in the implementation of watershed programmes along with the decentralization of power and resource management, this study emphasises the need to involve the community at all levels of the projects so as to encourage collective action for management of watershed resources.

\section{Conclusion and Recommendation}

Whereas the overall level of participation of Awoja watershed community was average $(81.9 \%)$ in this study, the low level of participation in economic participation (74.3\%) as exhibited by the results, points to limited monetary gains expected by the community from Awoja watershed. High poverty levels and insufficient products from the watershed creates a scenario for the community to reluctantly participate in watershed restoration activities. This research presents a conceptual and technical step towards the systematic assessment of the level of participation in Awoja watershed that will act as a baseline for further research.

The upcoming projects on restoration in Awoja should encourage active involvement of the community at all stages of the projects because they are key beneficiaries as well as great contributors of degradation.

\section{Acknowledgements}

The authors acknowledge and thank Regional Universities Forum for Capacity Building in Agriculture (RUFORUM) for financing the entire study and the research assistants Irene Mary Apiny, Margaret Awekonimungu and Acuu Simon Peter for being part of the data collection team.

\section{Statement of No Conflict of Interest}

The corresponding author indicates that she was a service provider for FIEFOC project but never worked in the study area hence did not influence the quality of this research. The co-authors have not declared any conflict of interest with respect to the research, authorship, and/or publication of this article.

\section{Definition of Terms}

$\begin{array}{ll}\text { DLG } & \text { District Local Government } \\ \text { FAO } & \text { Food and Agricultural Organisation } \\ \text { FGD } & \text { Focus Group Discussion } \\ \text { FSSD } & \text { Forest Sector Support Department } \\ \text { IUCN } & \text { International Union for conservation of Nature } \\ \text { KII } & \text { Key Informant interview } \\ \text { NU } & \text { Nature Uganda } \\ \text { TOT } & \text { Training of trainers } \\ \text { UWS } & \text { Uganda Wildlife Society } \\ \text { WMD } & \text { Wetland Management Department. }\end{array}$

\section{References}

[1] Arnstein, Sherry R. (1969). A Ladder of Citizen Participation. Journal of the American Planning Association, Vol. 35, No. 4 July, pp. 216-224.

[2] Akello, S. Turyahabwe, N. Okullo P and Agea J.G. (2016). Changes in Land use/cover change and perceived status of Awoja in eastern Uganda. African Journal of Environmental Science and Technology.

[3] Bahiigwa, G., Rigby, D. \& Woodhouse, P. (2005). Right target, wrong mechanism? Agricultural modernization and poverty reduction in Uganda. World Development, 33(3), 481-496.

[4] Begherian Rezan. (2013). Analysing community participation in watershed management program in Iran. App. Sci.Rep. 1(3) 2013: 79-86 Iran, Tehran.

[5] Binod, B. (2016). Community Forest and Forest Management in Nepal. American Journal of Environmental Protection, vol. 4, no. 3 (2016): 79-91.

[6] Cornwall, A. (2008). Unpacking 'participation': Models, meanings and practices. Community Development Journal, 43 (3), 269-283.

[7] Cleaver Frances (1999). Paradoxes of Participation: Questioning Participatory Approaches to Development Journal of International Development 11, 597-612.

[8] Devi Suman (2015). Community participation and sustainable livelihoods: A study on watershed management in Odisha. $P h D$ Thesis Roll No. 509HS305.

[9] FAO, IFAD and WFP. (2013). The State Of Food Insecurity in The World. The Multiple Dimensions of Food security Rome, FAO.

[10] German, L., Hussein, M., Getachew A., Waga M., Amede T. \& Stroud, A. (2007). Participatory Integrated watershed management: Evolution of concepts and methods in an eco-regional program of the eastern African highland. (AHI/ICRAF), Eastern Africa: African Highlands Initiative.

[11] Government of Uganda. (2015). National development plan Phase II. Kampala, Uganda.

[12] Kelinger, F. N. (1986). Foundations of Behaviour Research. London: Winston Publisher.

[13] Kunihira, R. 2014. Socio-cultural factors affecting women's participation in watershed resources Management in Chahi catchment, South-Western Uganda. MSc thesis in Integrated Watershed Management in the School of Pure and Applied Sciences of Kenyatta University, 124p. September, 2014

[14] Masika, A. (2014). Understanding participation in faith-based agricultural development initiatives: The Case of Caritas In Kasese District, Uganda Msc. Thesis. Agricultural Extension education, MUK.

[15] Mark, R. (1996). Research made` simple. A handbook for social workers pp.114. Thousand Oaks, London, New Delhi: SAGE Publications.

[16] Mbogga, M., Malesu, M.., De, L., J. (2014). Trees and watershed management in Karamoja, Uganda. Evidence on Demand, UK; iv +25 pp.

[17] Ministry of Water and Environment. (2013). The National Forest Plan 2011/12 - 2021/22 Directorate of Environment Affairs, Kampala, Uganda.

[18] Turyahabwe, N. (2006). Local capacity to manage Forestry Resources under a decentralized System of Governance: The case of Uganda. PhD Dissertation in Community Forestry, Stellenbosch University South Africa.

[19] Ong'or, D.O. (2005). Community participation in Integrate Water Resource Management: The case of the lake Victoria Basin. Kenya: Department of Agriculture.

[20] Palmer, M.A. (2009). Reforming Watershed Restoration: Science in Need of Application in Need of Science. University of Maryland Center for Environmental Science, Solomons, MD 20688, USA.

[21] Perkins, D.D., Brown, B.B. and Taylor R.B. 1996. The ecology of empowerment: predicting participation in community organizations. Journal of Social Issues, 52(1): 85-110.

[22] Rex, V. O. (2013). Knowledge Center on Climate Change. Southeast Asian Regional Center for Graduate Study and Research in Agriculture (SEARCA) College, 4031 Philippines: Los Baños, Laguna. 
[23] Safa S., M.A. (2015). Study Patterns of Public Participation in Integrated Watershed Management (Case Study: Catchment Taleghan). American Journal of Environmental Protection, vol. 3, no. 6 (2015): 187-192.

[24] Scott, J.(1998). Address to the seventh annual conference of the international association or the study of the common property, Vancouver,10-14 June.

[25] Sreedevi, T. K., Shiferaw, B., \& Wani, S.P. (2004). Adarsha watershed in Kothapally: drivers of higher impact. Global Theme on Agro ecosystems Report no. 10. Pantacheru 502 304.The National Gender Policy of 1999.India: Andhra Pradesh.

[26] Skinner S. (1995). Building Community Strengths, Community Development Foundation Stewart.

[27] Taylor, M. (1995). Empowerment and estate regeneration, Bristol: Policy Press.

[28] Stoker, G (1997), 'Local Political Participation’ in Hambleton, R et al (1997) New Perspectives on local governance: reviewing the research evidence, York: Joseph Rowntree Foundation, pp. 157-196.

[29] Sseguya, H. Mazur, E.R and Masinde, D. (2009). Harnessing Community Capitals for Livelihood Enhancement: Experiences from a Livelihood Program in Rural Uganda. Community Development 40(2): 123-138.

[30] Tesfaye, H.D. (2011). Assessment of sustainable watershed management approach. Case study lenche dima: tsegur eyesus and dijjil Watershed.

[31] Uganda Bureau of Statistics (UBOS) (2015). Statistical abstract. Kampala: Uganda Bureau of Statistics.

[32] Wani S.P., Sreedevi, T.K., Reddy, T., Venkateswarlu, B and Prasad, C.S. (2006). Community watershed for improved livelihoods through consortium approach in drought prone rain-fed areas. Journal of hydrological Research and development. 3: 55-77, Kothapally India: Adarsha Watershed.

[33] Weinberger, K. and Jütting, J.P. (2007). Women's participation in local organizations: conditions and constraints. World Development 29(8), pp. 1391-1404.

[34] World Bank. (2013). Development of the Awoja Catchment Management Plan in the Kyoga Water Management Zone Contract: 7164726.Final Stakeholder Engagement Report.

[35] Yin, R. (2006). Case Study Research: Design and Methods. Applied Social Research Methods series. Thousand Oaks, London: Sage Publications. 5: 25. 